\title{
Functional Characterization of a Gene Family Encoding Polygalacturonases in Phytophthora parasitica
}

\author{
Chih-Hang Wu, ${ }^{1}$ Hao-Zhi Yan, ${ }^{1}$ Li-Fei Liu, ${ }^{2}$ and Ruey-Fen Liou ${ }^{1,3}$ \\ ${ }^{1}$ Department of Plant Pathology and Microbiology, ${ }^{2}$ Department of Agronomy, and ${ }^{3}$ Institute of Biotechnology, \\ National Taiwan University, Taipei 106, Taiwan
}

Submitted 29 October 2007. Accepted 10 December 2007.

\begin{abstract}
Phytophthora parasitica is an oomycete plant pathogen that causes severe disease in a wide variety of plant species. In our previous study, we discovered a multigene family encoding endopolygalacturonases (endoPG) in Phytophthora parasitica. Here, we screened the genomic library of Phytophthora parasitica for the genes encoding endoPG named pppg2 through pppg10, and analyzed their functions. Results obtained by real-time quantitative reverse transcriptasepolymerase chain reaction demonstrated that some of these genes are highly induced during plant infection, which suggests their important roles in the pathogenesis of Phytophthora parasitica. Analysis by in-gel activity assay of recombinant proteins obtained from Pichia pastoris indicated that each of these genes encodes a functional endoPG. Investigation of the function of pppg genes in planta by a Potato virus $X$ agroinfection system in tobacco revealed that each pppg caused specific effects, varying from no symptoms to dwarfism, necrosis, leaf curl, silvery leaf, and cracks in leaf stalks. Appearance of these effects depends on the expression of a pppg protein with a normal active site in the apoplast. These results indicated that each pppg plays a distinct role in the decomposition of plant cell wall.
\end{abstract}

During plant infection, pathogens produce a diverse range of cell wall-degrading enzymes (Walton 1994), including cellulases, hemicellulases, and pectinases. The latter includes a group of enzymes that degrade pectin, a major component of the primary cell wall and middle lamella of plants. According to the mode of action, pectinase can be divided into three different groups: polygalacturonase (PG), pectate lyase, and pectin methyl esterase. PG can hydrolyze the $\alpha(1 \rightarrow 4)$ glycosidic bonds of pectin homogalacturonans by releasing monomers in a progressive fashion from the nonreducing ends of the polymer (exopolygalacturonase, EC 3.2.1.67) or internally cleaving the backbone of polygalacturonan (endopolygalacturonase [endoPG], EC 3.2.1.15).

Targeted mutagenesis of PG-encoding genes has demonstrated that PG is a virulence factor of several plant pathogenic fungi. Disruption of BcPGl (Botrytis cinerea polygalacturonase 1) reduces the virulence of Botrytis cinerea on host plants

C.-H. Wu and H.-Z. Yan contributed equally to this study.

Corresponding author: R.-F. Liou; E-mail: rfliou@ntu.edu.tw; Telephone: +886-2-3366-5208; Fax: +886-2-2362-0271.

* The $\boldsymbol{e}$-Xtra logo stands for "electronic extra" and indicates that one supplemental figure and two supplemental tables are published online. (ten Have et al. 1998). Mutation in the endoPG gene reduced the ability of Alternaria citri to cause black rot symptoms in citrus and the maceration of potato tissues (Isshiki et al. 2001). Gene replacement mutants of Claviceps purpurea, which lack endoPG activity, are nearly nonpathogenic in rye (Oeser et al. 2002). However, genetic evidence obtained by targeted inactivation does not always support an essential role of PG in fungal pathogenicity. Disruption of enpg-1, which encodes the major extracellular endoPG produced by Cryphonectria parasitica in culture, demonstrated that this endoPG is not required for the expression of Cryphonectria parasitica virulence in American chestnut stems (Gao et al. 1996). In Cochliobolus carbonum, targeted inactivation of both the exo- and endoPG genes resulted in a nearly complete loss of PG activity. However, the double mutant was still pathogenic in maize (Scott-Craig et al. 1998). Disruption of $p g 5$, which encodes endoPG, has no detectable effect on the virulence of Fusarium oxysporum f. sp. lycopersici in tomato (Garcia-Maceira et al. 2001). A possible explanation for these results is the presence of multigene families of endoPG in fungi, each gene performing defined biological tasks in the infection process. Recent study indicated that Botrytis cinerea, the cause of gray mold, contains at least six PG-encoding genes that are differentially expressed during interaction with plants and when grown in different carbon sources (ten Have et al. 2001; Wubben et al. 2000). BcPG recombinant proteins heterologously expressed by Pichia pastoris differ in several aspects, including specific activity, substrate preference, and mode of action. In addition, analysis by infiltration of recombinant proteins indicated the differential activity of these BcPG in causing necrosis in plants (Kars et al. 2005). Sclerotinia sclerotiorum secrets a large set of endoPG that differ in their catalytic properties and expression patterns. Of these endoPG, sspgl (Sclerotinia sclerotiorum polygalacturonase 1), sspg2, and sspg3 are up-regulated during colonization in healthy plant tissues, sspg 5 was induced in the final phase of maceration, and sspg6 and sspg7 were expressed constitutively throughout the infection process (Kasza et al. 2004; Li et al. 2004). As well, Chondrostereum purpureum, which causes silvery leaf disease on apple, contains a multigene family of endoPG and is the first basidiomycete reported to have an endoPG gene family (Williams et al. 2002).

In addition to their roles as cell wall-degrading enzymes, and thus virulence factors, endoPG function as avirulence determinants that elicit plant defense responses. CLPG1, an endoPG gene of Colletotrichum lindemuthianum, shows elicitor activity in tobacco (Nicotiana tabacum) that depends on a functional catalytic site (Boudart et al. 2003). Thus, CLPG1 might induce plant defense response through release of oligo- 
galacturonans (Ridley et al. 2001). BcPG1 of Botrytis cinerea, however, activates grapevine defense response, which is not related to its enzymatic activity (Poinssot et al. 2003).

Pathogens belonging to the genus Phytophthora can cause diseases in economically important crops such as potato, tomato, and soybean as well as valuable forest trees in North America and Europe. To unravel the mechanisms involved in the pathogenesis of Phytophthora spp., genes required for the degradation of the plant cell wall must be characterized. Recent studies have demonstrated that pipgl encodes an endoPG in Phytophthora infestans that causes late blight on potato and tomato (Torto et al. 2002). Also, Phytophthora cinnamomi contains a large endoPG gene family with 19 members (Götesson et al. 2002). Not much is known, however, about the proteins encoded by each of these genes. Previously, we found the expression of pppg1, which encodes endoPG in Phytophthora parasitica, induced during plant infection (Yan and Liou 2005). Furthermore, Southern hybridization results with pppg 1 as the probe suggested the presence of other sequences homologous to pppgl in the Phytophthora parasitica genome. In the present study, we cloned and analyzed the function of pppg genes and found that they encode functional endoPG and have distinct biological functions in planta.

\section{RESULTS}

Isolation and sequence analysis of the endoPG family from Phytophthora parasitica.

Although our previous study suggested the presence of genes homologous to pppgl in the Phytophthora parasitica genome
(Yan and Liou 2005), attempts to screen the genomic library with pppgl used as a probe did not reveal clones representing genes other than pppg1. As an alternative, we used the degenerated primers conPGF1 and conPGR1 for genomic polymerase chain reaction (PCR). Amplicons of the expected size were cloned, and analyses of sequences of 16 independent clones revealed seven distinct sequences homologous to endoPG genes, including two (conl and con7) that deviate significantly from pppg1. Southern blot analysis with conl and con7 used as probes revealed the presence of multiple bands (data not shown), indicating the existence of a multigene family of endoPG in Phytophthora parasitica. So, with conl and con 7 used as probes to screen the genomic library of Phytophthora parasitica, we obtained seven phage clones; three clones contained putative endoPG genes (pppg2-pppg9), as shown in Figure 1, and the other four contained sequences overlapping with the aforementioned clones or pppgl and, thus, are not described here. Of these putative endoPG genes, pppg6 is interrupted by one intron and the others (pppg2, pppg3, pppg4, pppg5, pppg7, pppg8, and pppg9) are intronless. In addition, a new gene was cloned by rapid amplification of cDNA ends (RACE) in a separate study and was named pppg 10 .

Except for pppg9, which has 512 residues, the genes contained from 358 to 390 amino-acid residues (Table 1). Analysis of the deduced amino-acid sequences predicted the existence of a signal peptide at the $\mathrm{N}$ terminus and an active consensus site (CXGGHGXSIGSVG) (Henrissat 1991) in each protein (Fig. $\mathrm{S} 1)$. pppg9 is distinguished from the other genes in having an additional N-terminal domain of about 150 amino acids immediately following the signal peptide. Search of the putative $\mathrm{N}$ -

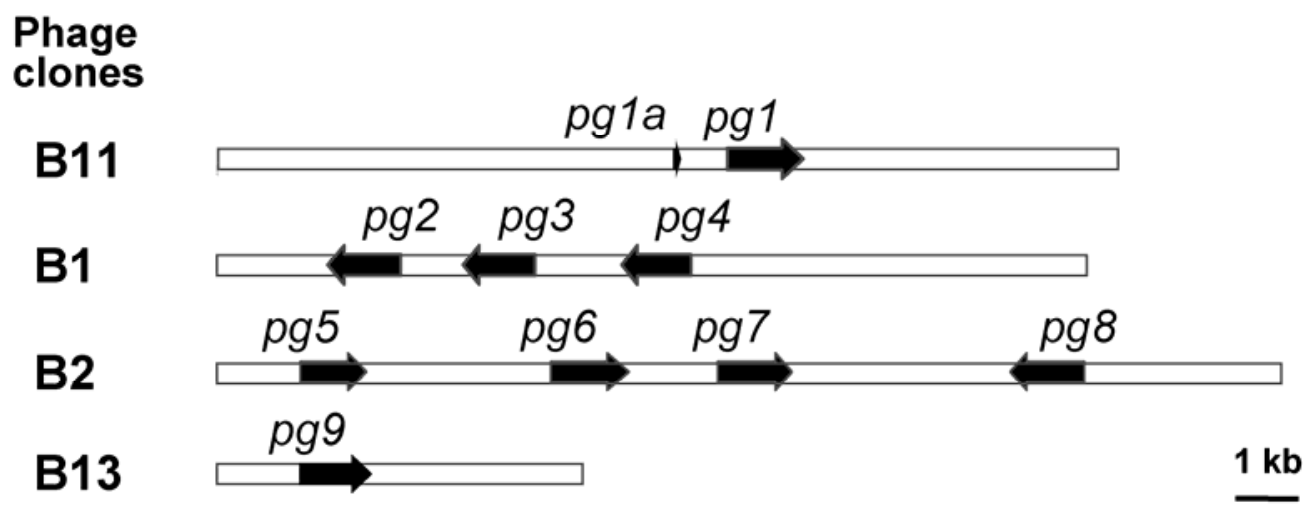

Fig. 1. Distribution of endopolygalacturonase genes of Phytophthora parasitica in the phage clones. Arrows indicate the localization of each gene, including pppg1 (AY697926), pppg2 (EU041943), pppg3 (EU041944), pppg4 (EU041945), pppg5 (EU041946), pppg6 (EU041947), pppg7 (EU041948), pppg8 (EU041949), and pppg9 (EU041950).

Table 1. Characteristics of proteins encoded by the endopolygalacturonases genes of Phytophthora parasitica

\begin{tabular}{|c|c|c|c|c|c|c|c|}
\hline$\overline{\text { Gene }}$ & Accession number & Nucleotides & Amino acids/ cleavage site ${ }^{a}$ & pI & Mol. mass ${ }^{\mathrm{b}} \mathrm{X} / \mathrm{Y}$ (kDa) & N-glycosylation site ${ }^{c}$ & Groupd $^{d}$ \\
\hline pppg $1^{\mathrm{e}}$ & AY697926 & 1,176 & $391 / 20$ to 21 & 5.2 & $40 / 75$ to 200 & 11 & I \\
\hline pppg 2 & EU041943 & 1,143 & $380 / 20$ to 21 & 8.9 & $37 / 43$ & 1 & III \\
\hline pppg3 & EU041944 & 1,143 & $380 / 20$ to 21 & 9.3 & $37 /-$ & 1 & - \\
\hline pppg4 & EU041945 & 1,089 & $362 / 20$ to 21 & 6.2 & $35 / 43$ & 0 & II \\
\hline pppg 5 & EU041946 & 1,083 & $360 / 20$ to 21 & 5.9 & $35 / 43$ to 50 & 2 & IV \\
\hline pppg6 & EU041947 & 1,092 & $363 / 20$ to 21 & 5.2 & $36 / 45$ to 55 & 0 & II \\
\hline pppg7 & EU041948 & 1,077 & $358 / 17$ to 18 & 4.1 & $35 / 55$ to 70 & 1 & I \\
\hline pppg8 & EU041949 & 1,086 & $361 / 20$ to 21 & 9.5 & $35 / 40$ & 0 & III \\
\hline pppg9 & EU041950 & 1,539 & $512 / 19$ to 20 & 4.0 & $50 /-$ & 2 & - \\
\hline pppg10 & EU041951 & 1,176 & $391 / 20$ to 21 & 5.0 & $39 / 43$ & 9 & III \\
\hline
\end{tabular}

${ }^{a}$ Location of the cleavage site of the signal peptide that was predicted with use of SignalP 3.0 (Bendtsen et al. 2004).

${ }^{\mathrm{b}}$ Molecular mass was estimated according to the deduced amino acid sequence (X) or mobility of the recombinant protein obtained from yeast on a sodium dodecyl sulfate polyacrylamide gel (Y).

${ }^{\mathrm{c}}$ Putative N-linked glycosylation site was predicted by use of PROSCAN.

${ }^{\mathrm{d}}$ Grouping was assigned according to the results obtained from agroinfection assays. - indicates that these genes were not analyzed in this experiment.

e Yan and Liou (2005). 
linked glycosylation site indicated that the endoPG genes may contain one (pppg2, pppg3, and pppg7), two (pppg5 and pppg9), or nine (pppg10) N-glycosylation sites, and some (pppg4, pppg6, and pppg8) contained no site (Table 1). In addition, pppg2 and pppg3 contained polyglutamine regions near the $\mathrm{N}$ terminus.

To examine the relation between the endoPG genes of Phytophthora parasitica and those from other organisms, we constructed a phylogenetic tree on the basis of multiple sequence alignment of the endoPG genes from Phytophthora parasitica, Phytophthora infestans (Torto et al. 2002), Phytophthora cinnamomi (Götesson et al. 2002), fungi, plants, and bacteria (Fig. 2). The endoPG of Phytophthora spp., fungi, plants, and bacteria are separated into distinct groups, with Phytophthora endoPG closer to fungal endoPG than to plant and bacterial endoPG. Furthermore, endoPG from Phytophthora spp. were clustered into two groups: one of genes with 0,1 , or $2 \mathrm{~N}$-glycosylation sites and the other of genes, including pppg 1 and

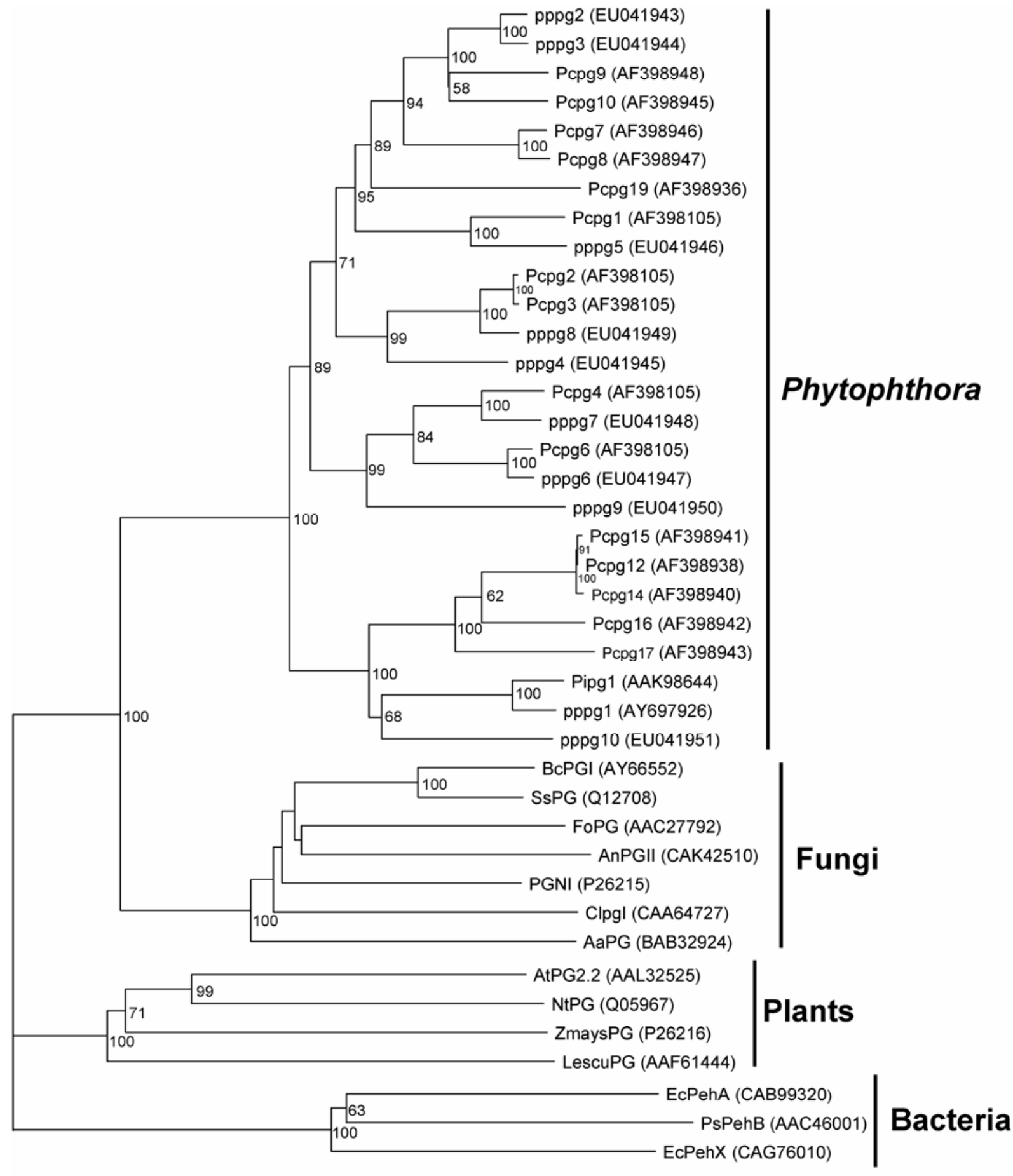

0.1

Fig. 2. Phylogenetic analysis of the polygalacturonase genes. The phylogram was generated by the neighbor-joining method as implemented in PAUP* 4.0 beta. Numbers beside each node indicate bootstrap values as a percentage of 1,000 replicates. The accession number of each gene is shown in the parentheses. Exopolygalacturonases from bacteria were used as the outgroup. 
pppg10, with multiple N-glycosylation sites. Some genes from the two Phytophthora spp. appearing in pairs were Pcpgl and pppg5, Pcpg2/Pcpg3 and pppg8, Pcpg4 and pppg7, and Pcpg6 and pppg6.

\section{Gene expression.}

To determine whether the endoPG genes are expressed by Phytophthora parasitica during infection of its host plant, detached tomato leaves were inoculated with zoospores of Phytophthora parasitica for quantification of gene expression by real time quantitative reverse transcriptase (qRT)-PCR. Raw data obtained from qRT-PCR were normalized with that of Ubc and WS21, which encode ubiquitin-conjugating enzyme and $40 \mathrm{~S}$ ribosomal protein, respectively. As compared with the expression at the stage of germinated cysts, at $12 \mathrm{~h}$ postinoculation (hpi), the expression of pppg4, pppg6, and pppg7 was upregulated, peaking at 48 hpi and declining at 72 hpi (Fig. $3 \mathrm{~A}$, Table S1). The expression of pppg1, known to be induced in planta (Yan and Liou 2005), displayed a similar expression pattern. The expression of pppg 2 and pppg10 in the germinated cysts was too low to be used as a reference but was verified by RT-PCR and agarose gel electrophoresis (Fig. 3B). The expression of the other genes, pppg3, pppg5, pppg8, and pppg9, was not detectable in germinated cysts or in diseased plants, even though cDNA clones of pppg3, pppg8, and pppg9 were obtained by RACE with RNA prepared from inoculated plants (data not shown).

\section{In-gel activity assay of recombinant proteins obtained} from the yeast Pichia pastoris.

To determine whether endoPG genes encode proteins with enzymatic activity, recombinant proteins for pppg2, pppg4, pppg5, pppg6, pppg7, pppg8, and pppg10 were expressed in Pichia pastoris and then underwent in-gel activity assay. pppg3 was not analyzed due to its $96 \%$ identity with the coding sequence of pppg2, and pppg9 will be investigated in a separate study. Western blot analysis with anti-6xHis-tag antibody used as the primary antibody revealed the recombinant proteins of pppg2, pppg4, pppg8, and pppg10 as single bands and those of pppg5, pppg6, and pppg 7 as double bands, ranging from 37 to $70 \mathrm{kDa}$ (Fig. 4A), slightly larger than the sizes based solely on deduced amino-acid sequences (Table 1). Further analysis by ingel activity assay revealed the activity band of each recombinant protein with a size similar to that shown by Western blot analysis (Fig. 4B). The recombinant protein of pppgl was included in this experiment as a control (Fig. 4A and B, lane 1). Although pppgl and pppg10 contain multiple putative N-glycosylation sites (Table 1), the recombinant protein of pppg10 appeared as a condensed band of approximately $43 \mathrm{kDa}$. As well, although no $\mathrm{N}$-linked glycosylation site was identified in pppg4, pppg6, and pppg8, the protein sizes were larger than those of deduced amino acid sequences.

\section{Functional analysis of the endoPG genes by Potato virus $X$ (PVX) agroinfection assay.}

To examine the function of proteins encoded by the endoPG genes, we used PVX as a vector to systemically express the endoPG proteins in the tobacco Nicotiana benthamiana. The coding sequence downstream of the signal peptide of each endoPG gene was subcloned into pgR106:SP, in-frame with the signal peptide of tobacco PR1a, for secretion of the recombinant protein into the apoplast. Systemic leaves of the infiltrated plants were examined under white and UV light after infiltration. Furthermore, cross-sections of these leaves were examined for changes in morphology of cells. Effects caused by the recombinant proteins could be classified into the following four groups (Table 1).
Group I effects, with pppgl and pppg7 expression, were no significant change in systemic leaves as compared with plants mock-inoculated or infiltrated with the empty vector (pgR106: $\mathrm{SP})$ at 10 days postinfiltration (dpi), although a slight symptom of silvery leaf was observed with pppg7 (Fig. 5A, 6A and B). Staining of leaves with ruthenium red revealed severely deformed mesophyll cells of pppg7-treated plants (Fig. 6C). Infiltration with pgR106:pppgl resulted in slight changes as compared with infiltration with the empty vector.

Group II effects, with pppg4 and pppg6 expression, were dwarf phenotypes (Fig. 5B). New leaves curled toward the back at $4 \mathrm{dpi}$, and their growth was slightly stunted. As the leaves expanded in size, they became heavily wrinkled and then showed necrotic spots with shot holes that appeared as spots of green fluorescence under UV light (Fig. 6A and B). Also, cross-wise cracks appeared on the leaf stalks (data not shown). These effects were predominant on the upper third and fourth leaves relative to the infiltrated ones on the test plants. Analysis of cross-sections of leaves treated with pppg4 and pppg6 showed deformed palisade and spongy mesophyll cells with barely any intercellular space left (Fig. 6C).

Group III, with pppg2, pppg8, and pppg10 expression, were yellowing and dwarfism (Fig. 5B). Similar to group II effects, new leaves of plants treated with pppg2, pppg8, and pppg10 curled up on emergence and leaf growth was stunted. As they
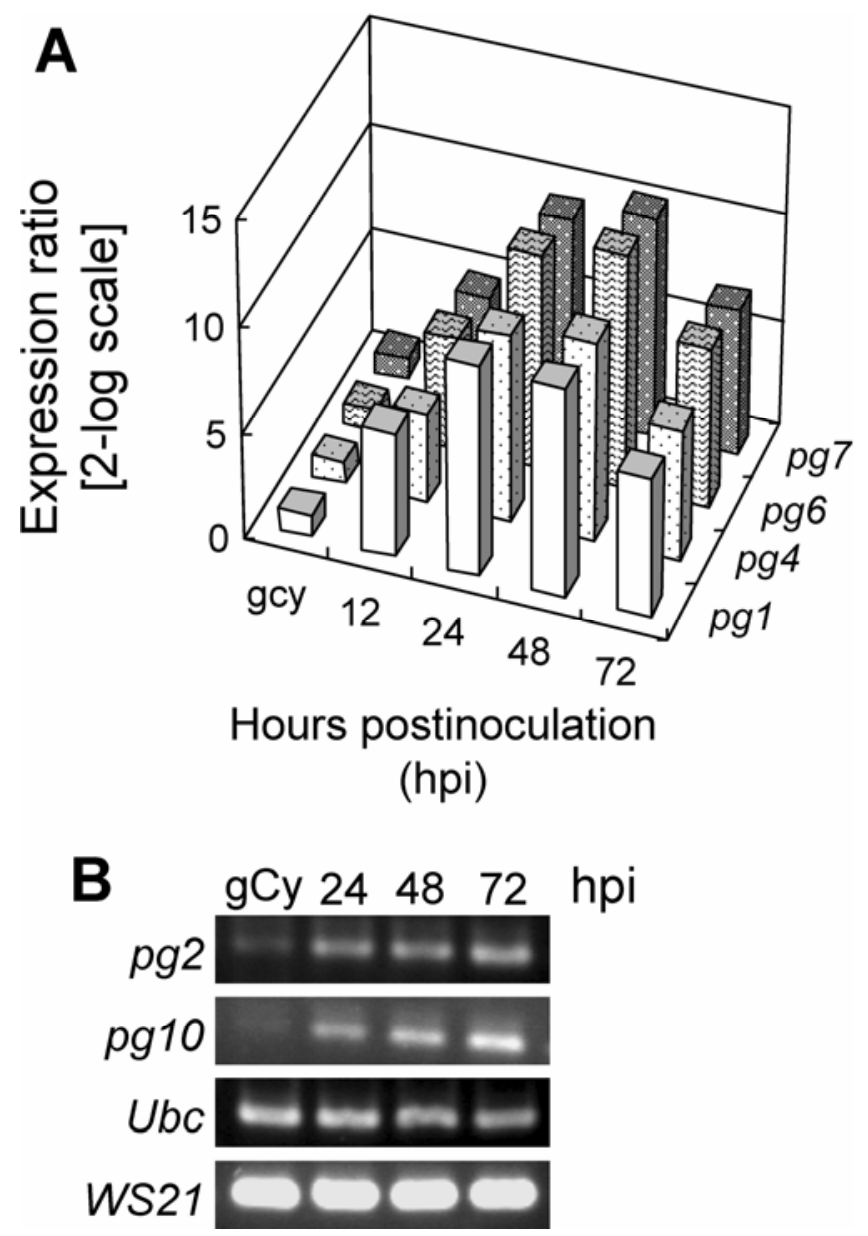

Fig. 3. Expression of pppg genes in tomato infected with Phytophthora parasitica. Following inoculation by zoospores, RNA was isolated from inoculated tomato leaves at the indicated times and was analyzed by $\mathbf{A}$, real-time quantitative reverse transcriptase-polymerase chain reaction (qRT-PCR) and B, RT-PCR followed by agarose gel electrophoresis. Raw data obtained from qRT-PCR were normalized to that of WS21 and Ubc as the internal control. $\mathrm{gCy}=$ germinating cysts. 
grew, the leaves became yellowed and wrinkled, with some necrosis visible under UV light (Fig. 6A and B). These effects were predominant on the upper third and fourth leaves of the test plants. On examination of leaf cross-sections, the morphology of the mesophyll was changed similar to that of plants treated with pppg6, with the disappearance of the intercellular space (Fig. 6C).

Group IV effects, with pppg5 expression, were a phenotype of silvery leaf (Fig. 5B), with the mesophyll cells severely deformed (Fig. 6C) at $10 \mathrm{dpi}$. In addition, similar to group II effects, pppg 5 expression resulted in the appearance of cracks on the leaf stalks of systemic leaves (Fig. 7A). Examination of the cross-sections showed cracked leaf stalks with more intercellular space than leaf stalks of plants infiltrated with the empty vector (Fig. 7B and C). Furthermore, epidermal cells were detached from the wax cuticle layer as compared with cells from plants infiltrated with the empty vector (Fig. 7D and E).

To determine whether these effects were due to the enzymatic activity of endoPG, two types of mutants were constructed for each pppg gene: i) SPd, with the signal peptide of PR1a deleted to prevent secretion of the recombinant proteins into the apoplast fluid, and ii) $D / E$, with two aspartic acid resi-

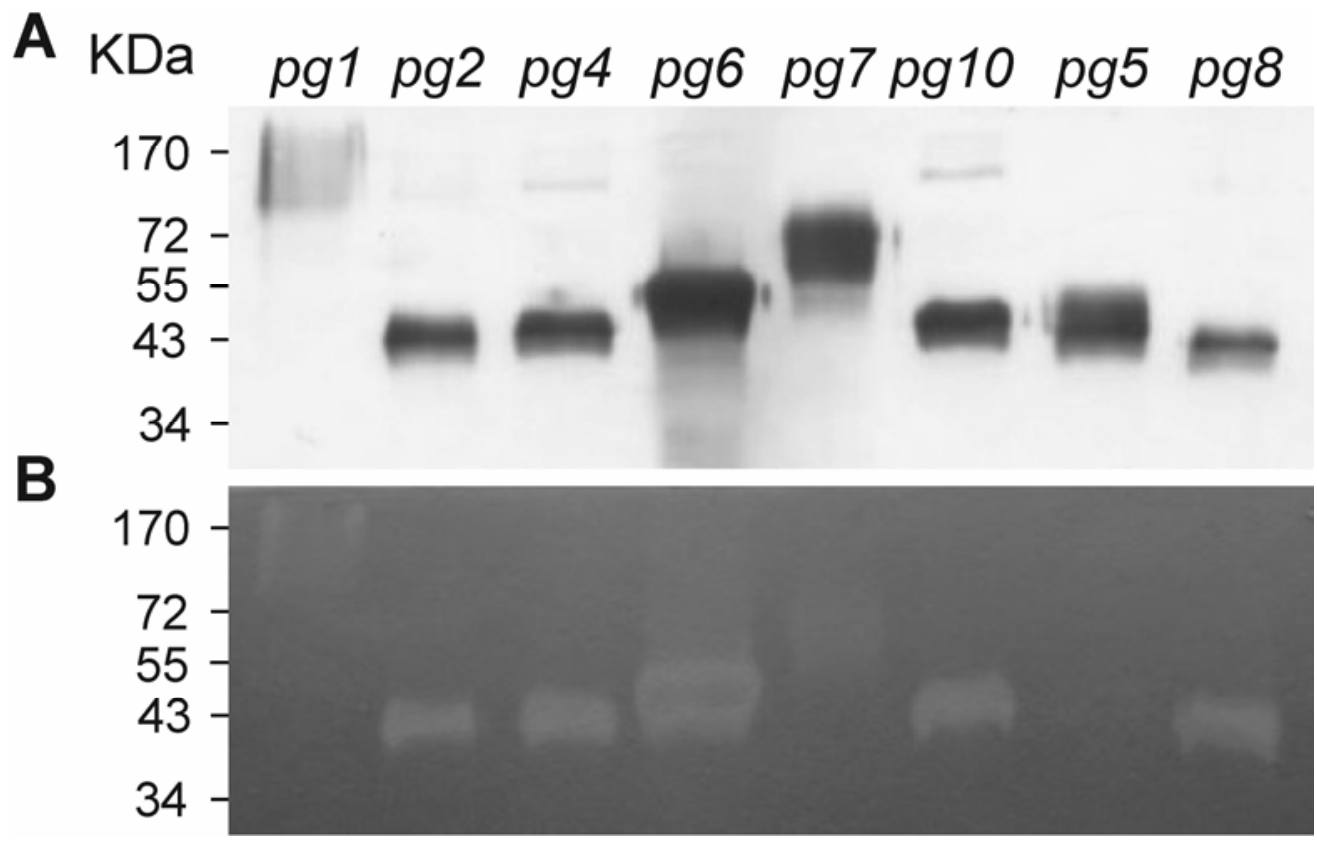

Fig. 4. Analysis of the pppg recombinant proteins heterologously expressed in Pichia pastoris. Recombinant proteins were analyzed by sodium dodecyl sulfate-polyacrylamide gel electrophoresis, followed by A, Western blot analysis with anti-6xHis-tag antibody used as the primary antibody or B, in-gel polygalacturonase activity assay with polygalacturonic acid used as the substrate.

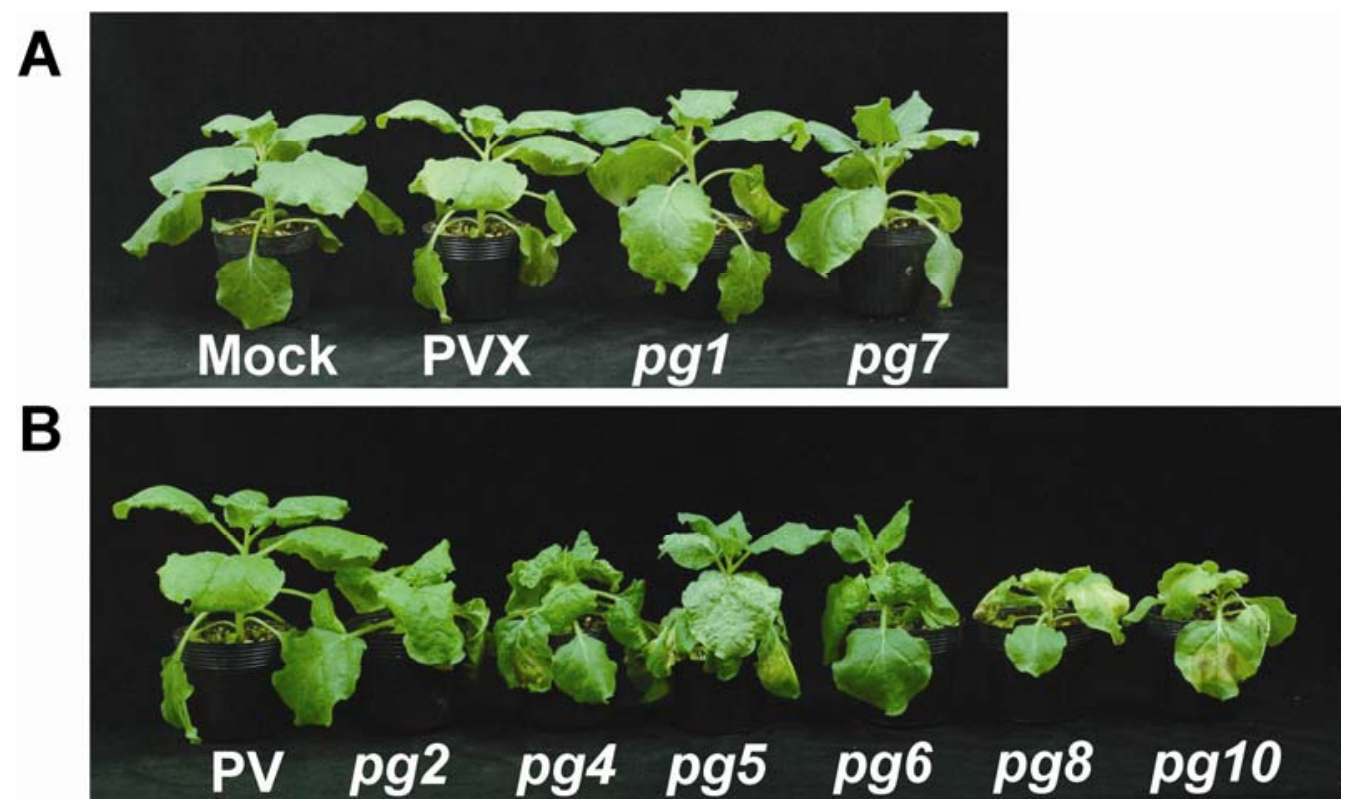

Fig. 5. Symptoms caused by the systemic expression of pppg genes in Nicotiana benthamiana with Potato virus $X$ (PVX) used as the vector. N. benthamiana plants were infiltrated with a cell suspension of Agrobacterium tumefaciens harboring pgR106:SP (PVX; the empty vector) or pgR106:pppg as specified. Mock indicates plants were infiltrated with the solution MMA (10 mM morpholineethanesulfonic acid, $\mathrm{pH} 5.6,10 \mathrm{mM} \mathrm{MgCl}{ }_{2}, 200 \mu \mathrm{M}$ acetosyringone), used to resuspend the bacteria. The plants were photographed 10 days postinfiltration. A, group I and B, groups II to IV. 
dues essential for the enzymatic activity of endoPG replaced with glutamic acids (Armand et al. 2000). Nicotiana benthamiana infiltrated with either $S P d$ or $D / E$ mutants of any pppg gene developed and grew normally like those treated with the empty vector, which indicates that the aforementioned effects indeed resulted from the enzymatic activity of the endoPG present in the apoplast (Fig. 8).

\section{DISCUSSION}

The plant cell wall provides a physical barrier to infection by pathogens. To invade the host, pathogens need to secrete pectinases, which degrade pectins embedded in the plant cell wall. Although interest in pectinases of Phytophthora spp. arose from the early 1970s (Cole 1970), our knowledge about these proteins is limited. Only a small number of genes encoding pectinases in Phytophthora spp. have been characterized in any detail (Götesson et al. 2002; Torto et al. 2002; Yan and Liou 2005). In this study, we cloned and analyzed the function of nine endoPG genes from Phytophthora parasitica. Together with pppgl reported previously by our laboratory (Yan and Liou 2005), 10 endoPG genes have been identified in this pathogen. Phylogenetic analysis indicated that endoPG of Phytophthora spp. form a cluster distinct from those of fungi and plants. Furthermore, endoPG of Phytophthora spp. are grouped into two clades, one heavily and the other lightly glycosylated. A multigene family of PG with 19 members has been identified in P. cinnamomi (Götesson et al. 2002). In the phylogenetic tree, some pppg genes are closely related to certain Pcpg genes of Phytophthora cinnamomi, which suggests that they may have evolved prior to their speciation and are thus orthologs. In contrast, as was found with some Pcpg genes (Pcpg7 to Pcpg8, Pcpg2 to Pcpg3, and Pcpg12 to Pcpg 15), pppg 2 is tightly related to pppg3, very likely because of a recent gene duplication, a phenomenon also found in other secretory proteins of Phytophthora spp. (Jiang et al. 2006). In addition, no gene closely related to pppg 9 or pppg 10 was identified in Phytophthora cinnamomi, although their respective homologs were found in Phytophthora ramorum by database search (data not shown). Together, these results support the divergence of endoPG genes before species separation within the genus Phytophthora, and moreover, the duplication of certain endoPG genes could still take place after the speciation event, with the formation of large endoPG gene families in these pathogens.

To determine whether these pppg genes are indeed expressed, qRT-PCR of RNA isolated from plants inoculated with zoospores of Phytophthora parasitica revealed expression of pppg4, pppg6, and pppg7 similar to that of pppg1-upregulated at $12 \mathrm{hpi}$ and peaking at $48 \mathrm{hpi}$-which suggests their importance in the early phase of plant infection. The expression of other genes, however, was very low or even undetectable. The expression of pppg 2 and pppg 10 was detected in inoculated plants but was very low in germinated cysts, which indicates that their expression is induced in planta as well. In Botrytis cinerea, Bcpg1 through Bcpg6 are differentially expressed, depending on stage of infection and host (ten Have et al. 2001). Also, studies of Sclerotinia sclerotiorum revealed that different endoPG genes are expressed consecutively during pathogenesis: $p g 1, p g 2$, and $p g 3$ are expressed during invasion and colonization and $p g 5$ in the late stage of maceration, but $p g 6$ and $p g 7$ are constitutively expressed across the colonization process (Kasza et al. 2004). Like Botrytis cinerea and Sclerotinia sclerotiorum, Phytophthora parasitica can infect a large number of plants. Further experiments will help elucidate the detailed expression pattern of pppg genes in terms of host and stage of infection by Phytophthora parasitica.
The deduced amino-acid sequences in the active site of the 10 pppg genes are highly conserved. Analysis of the expression of these genes in Pichia pastoris followed by in-gel activity assay demonstrated that each of the recombinant proteins contained the enzymatic activity of endoPG. The activity of pppg5 and pppg7, however, was weaker than that of other genes, which indicates distinct biochemical characteristics of

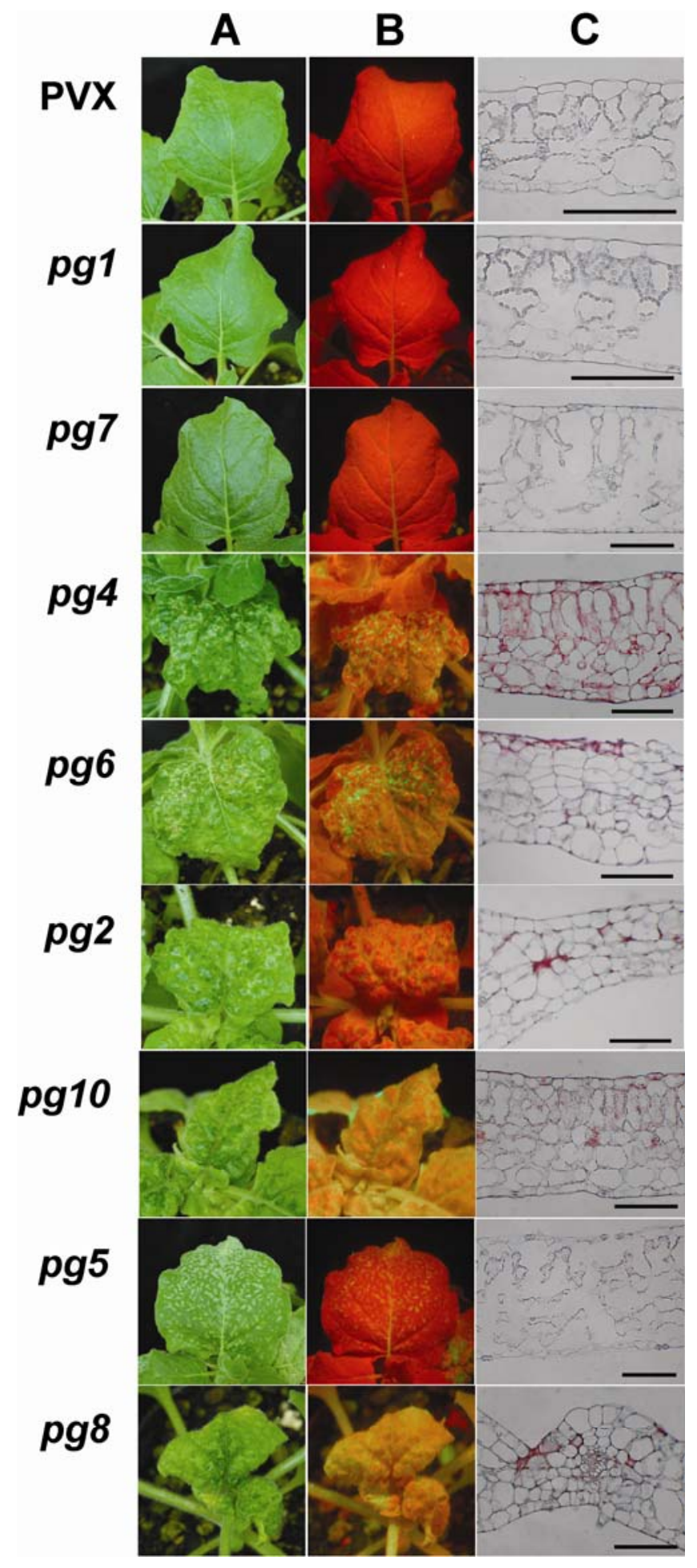

Fig. 6. A close-up of symptoms caused by the expression of pppg genes on leaves of Nicotiana benthamiana. $N$. benthamiana plants were infiltrated with Agrobacterium tumefaciens harboring pgR106:SP (PVX; the empty vector) or pgR106:pppg as specified. A, At 10 days postinfiltration, the plants were examined under white light, B, UV light, or $\mathbf{C}$, cut into crosssections and stained with ruthenium red. Bars correspond to $100 \mu \mathrm{m}$. 
these two proteins, such as substrate preference and protein stability, than those of other genes. In Botrytis cinerea, polygalacturonate was shown to be a poor substrate for BcPG1 and BcPG4 as compared with BcPG2, BcPG3, and BcPG6 (Kars et al. 2005). Of special interest, although predicted to contain nine $\mathrm{N}$-glycosylation sites and closely related to pppg1, pppg10 appeared as a condensed protein band of $43 \mathrm{kDa}$, in sharp contrast to pppgl, with its $11 \mathrm{~N}$-glycosylation sites and range in size from 75 to $200 \mathrm{kDa}$, very likely due to a differential glycosylation of the pppgl protein (Yan and Liou 2005). Some pppg genes (pppg4, pppg6, and pppg8) did not contain any N-glycosylation sites. However, their corresponding proteins appear to be larger than those of the deduced amino acid sequences. Thus, other types of post-translational modification might be required for the maturation of these proteins.

Like Phytophthora parasitica and Phytophthora cinnamomi, many plant pathogens are known to contain a multigene family of endoPG (Williams et al. 2002; Wubben et al. 1999). The number of endoPG genes may depend on the host range of a pathogen (Esquerré-Tugayé et al. 2000). Search of the Joint Genome Initiative (JGI) database (United States Department of Energy), however, suggested the presence of various endoPG homologs in the genome of Phytophthora sojae, which is known to have a narrow host range (Yan and Liou 2005). Thus, the number of endoPG genes is not related to host range. The composition of plant cell walls varies significantly among cell types and species (Vorwerk et al. 2004). For pathogens to succeed in infection, a profile of endoPG that function differently in plant tissues may be required to compensate for the complicated composition and structure of pectins in the cell walls. To address this possibility, we expressed the pppg genes ectopically in plants, using the binary vector pgR106 (Lu et al. 2003). The pppg genes were mobilized systemically along with the PVX vector, and their proteins were secreted into the apoplast of the infiltrated plants. Plant cell walls are highly hydrated, and proteins less than $50 \mathrm{kDa}$ diffuse freely through a typical wall in less than $1 \mathrm{~h}$ (Baron-Epel et al. 1988). Thus, once secreted, the pppg proteins may have a very good chance to reach their targets in the middle lamella, which is essential for cell-cell adhesion, and thereby cause distinct effects, depending on how and where they worked. Effects caused by the pppg proteins in tobacco were classified into four groups (Table 1). pppg1 and pppg7 (group I) failed to cause significant effects, perhaps because of their large molecular mass, greater than 50 $\mathrm{kDa}$ (Table 1; Fig. 4), which assumes that these two proteins were modified in a similar way in plants. Treatment with other pppg genes, in contrast, caused obvious effects in the plants, which appeared only when pppg proteins with normal active sites were secreted into the apoplast. Why these pppg genes functioned differently in planta, however, is not easy to explain. No relation was found between the effects and characteristics of the proteins, such as isoelectric point values, number of putative N-glycosylation sites, phylogeny, and locations of these genes in the genome of Phytophthora parasitica. In Botrytis cinerea, BcPG were found to differ in many aspects, including maximum activity, $K_{\mathrm{m}}$, optimal $\mathrm{pH}$, and mode of action, which underlie their differences in necrotizing activity (Kars et al. 2005). Analysis of the recombinant pppg proteins by in-gel activity showed the activity of pppg 5 and pppg 7 much weaker than that of others, which suggests differences in biochemical properties of the pppg proteins. Thus, the differential effects caused by each pppg might reflect the complicated interplay between the enzyme and the microenvironment it worked; the latter involved the composition and structure of the cell wall at a particular stage in leaf development. To our knowledge, this is the first demonstration that systemic expression of different endoPG genes from a pathogen caused distinct effects in plants.

In response to infection by the systemic fungus Chondrostereum purpureum, apple tree shows the 'silvery leaf' symptom, which is due to airspaces caused by partial separation of the epidermal cells from the palisade cells (Spiers et al. 1987), and endoPG produced by Chondrostereum purpureum is believed to be responsible for the development of the symptom (Miyairi et al. 1977). In our study, the expression of pppg5 also caused a phenotype of silvery leaf with epidermal cells detached from the wax cuticle layer (Fig. 7D), which provided the first direct evidence that expression of a single endoPG from a pathogen can cause silvery leaf in plants.

In addition to their role as cell wall-degrading enzymes, and thus virulence factors, some endoPG also function as avirulence factors that elicit the plant defense response (Boudart et
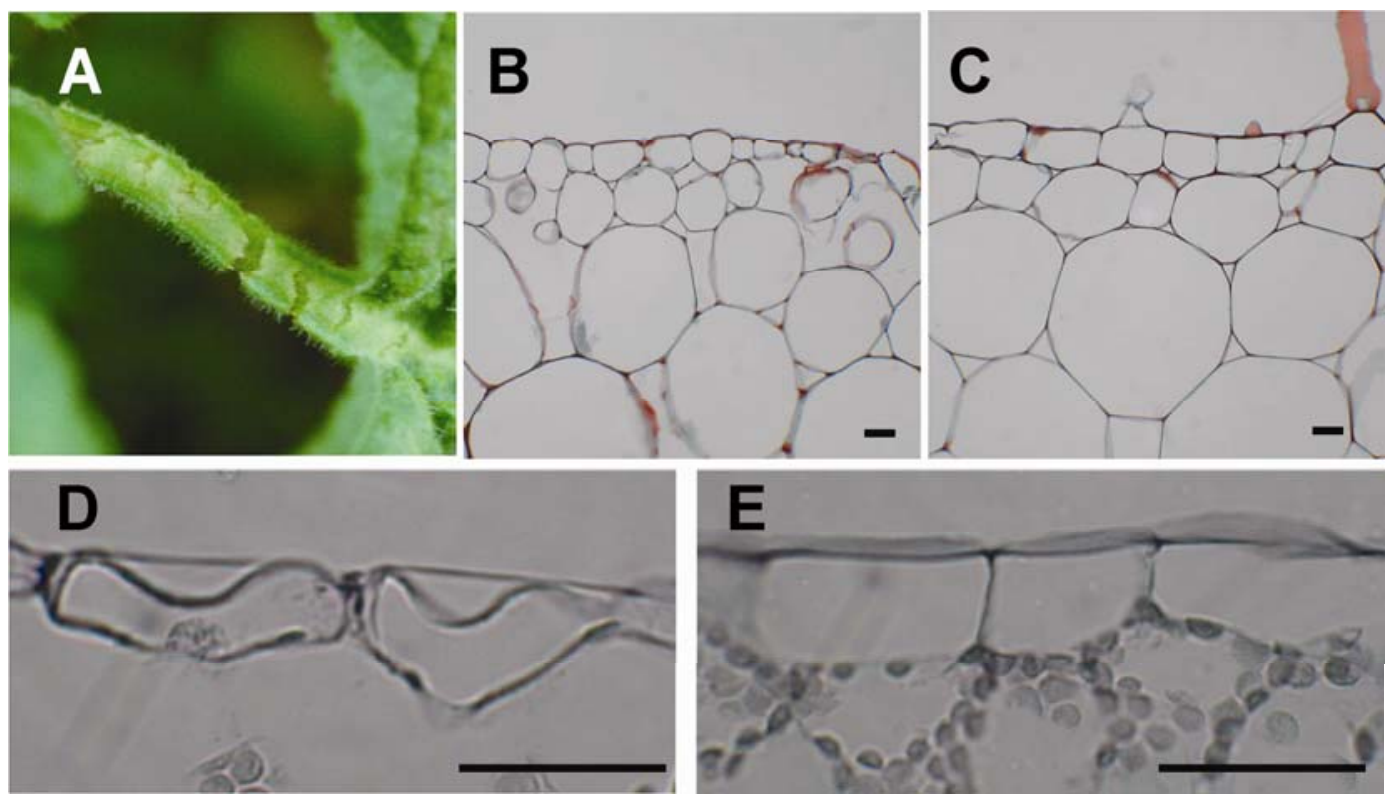

Fig. 7. Effect of pppg5 in Nicotiana benthamiana. A, B, and D, Plants infected with Agrobacterium tumefaciens harboring pgR106:pppg5 or C, and E, pgR106:SP (PVX; the empty vector). Ten days after infection, plants were examined under white light (A) and were cut into cross-sections and stained with ruthenium red for microscopy observation of the cortical region of a leaf stalk (B and C) or epidermal cells ( $\mathrm{D}$ and $\mathrm{E}$ ). Bars correspond to $25 \mu \mathrm{m}$. 
al. 2003; Poinssot et al. 2003). That pppg genes may cause plant defense response is now under investigation.

\section{MATERIALS AND METHODS}

Phytophthora parasitica strains and growth conditions.

Phytophthora parasitica 98151 (mating type A2) was provided by P. J. Ann (Taiwan Agricultural Research Institute, WuFeng, Taiwan) and was stored in sterile distilled water. For preparation of nucleic acids, one culture block of Phytophthora parasitica from 5\% V8 juice agar (5\% Campbell's V8 juice, $0.02 \% \mathrm{CaCO}_{3}, 2 \%$ agar) was transferred into a sterile 250-ml flask containing $100 \mathrm{ml}$ of $5 \% \mathrm{~V} 8$ juice medium (5\% Campbell's V8 juice and $0.02 \% \mathrm{CaCO}_{3}$ ) and was incubated at $25^{\circ} \mathrm{C}$ in the dark for 7 days. Following harvest by filtration, the mycelia were frozen instantly in liquid nitrogen and were lyophilized and stored at $-80^{\circ} \mathrm{C}$ until use

Isolation of genes encoding polygalacturonase in Phytophthora parasitica and sequence analysis.

DNA was extracted from mycelia of Phytophthora parasitica by use of DNeasy plant mini kit (Qiagen, Basel, Swit- zerland). Two sets of degenerated primers, conPGF1 and conPGR1 (Table S2), were designed according to amino-acid sequences conserved among endoPG of Phytophthora parasitica (pppg1; Yan and Liou 2005), Phytophthora cinnamomi (PcPG2, PcPG3, and PcPG9; Götesson et al. 2002), and Phytophthora ramorum (gwEuk.91.29.1, gwEuk.91.45.1, and fgenesh1_pm.C_scaffold_91000005; JGI database). Genomic PCR involved use of these primers, with the reaction mixture $(50 \mu \mathrm{l})$ consisting of $500 \mathrm{ng}$ of genomic DNA, $6 \mu \mathrm{M}$ primers, $0.2 \mathrm{mM}$ deoxynucleoside triphosphate, $1 \times$ PCR buffer, and $2 \mathrm{U}$ DyNazyme II DNA polymerase (Finnzyme, Espoo, Finland) and denaturation at $96^{\circ} \mathrm{C}$ for $5 \mathrm{~min}$, followed by 25 cycles of amplification $\left(96^{\circ} \mathrm{C}\right.$ for $20 \mathrm{~s}, 52^{\circ} \mathrm{C}$ for $20 \mathrm{~s}, 72^{\circ} \mathrm{C}$ for $\left.20 \mathrm{~s}\right)$ and a final extension for $5 \mathrm{~min}$ at $72^{\circ} \mathrm{C}$ in a Thermocycler (GeneAmp PCR system 2400, Perkin-Elmer, Foster City, CA, U.S.A.). After analysis by agarose gel electrophoresis, amplicons of the expected size were cloned and analyzed. Sequences representing putative endoPG were used to screen a genomic library of Phytophthora parasitica as described previously (Yan and Liou 2005). In addition, pppg10 was cloned by RACE as described by Yan and Liou (2005). Nucleotide and amino-acid sequence homology searches were performed with the National Center for

\section{WT $\quad D / E \quad S P d$}
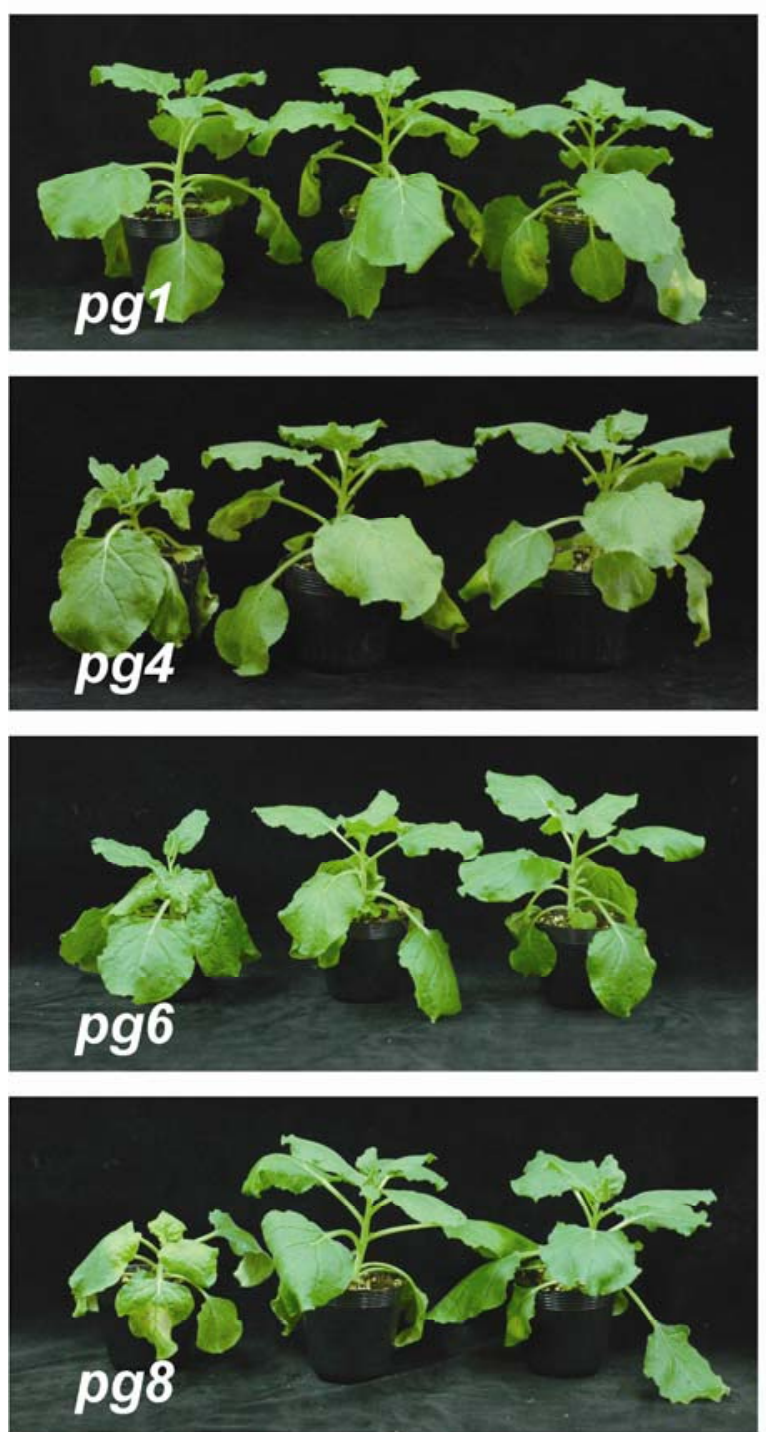

WT $\quad D / E \quad S P d$
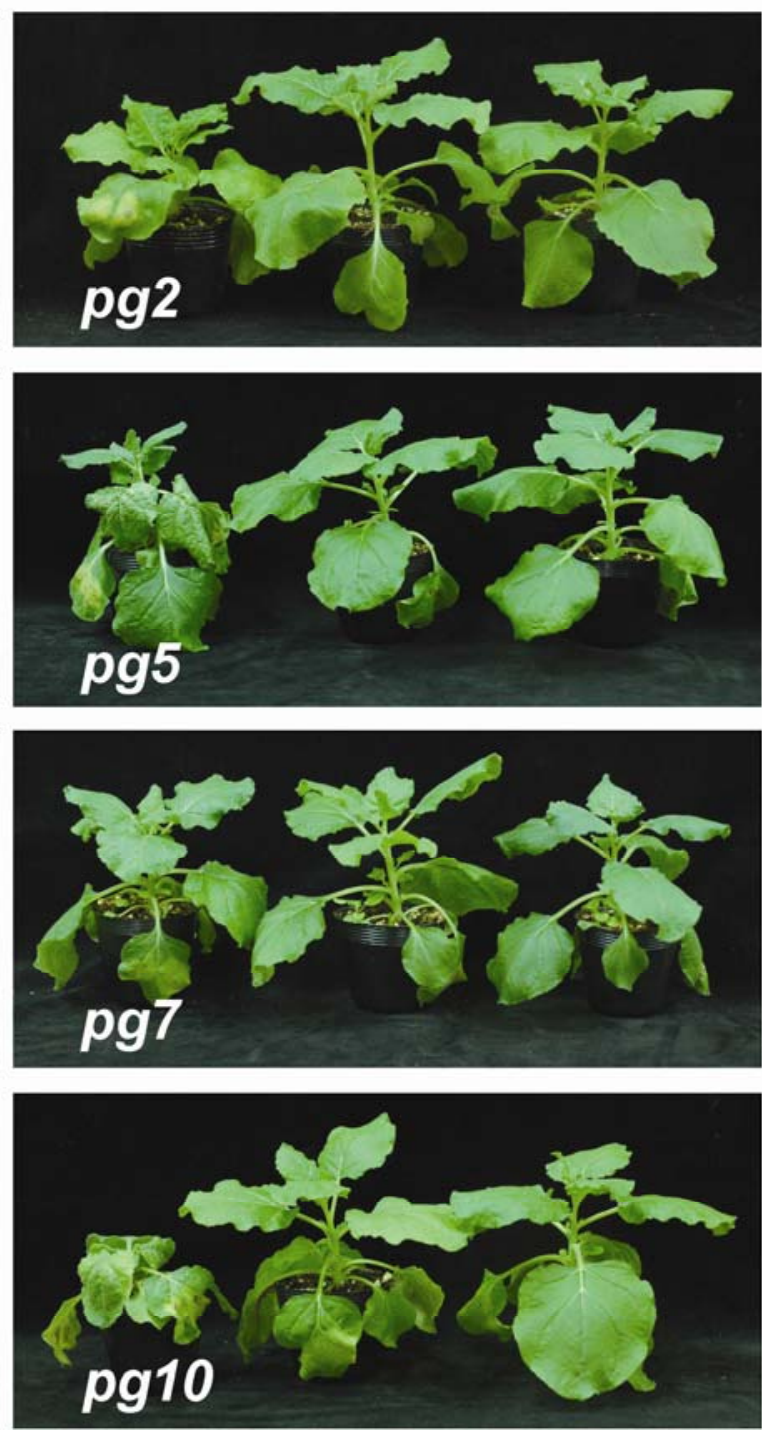

Fig. 8. Effect of pppg genes on Nicotiana benthamiana depends on the expression of pppg as secretory proteins with normal active sites. N. benthamiana plants were infiltrated with a cell suspension of Agrobacterium tumefaciens harboring pgR106:pppg (wt), pgR106:pppg with mutations in the putative active site $(D / E)$, or pgR106:pppg without a signal peptide $(S P d)$. Plants were photographed 10 days postinfiltration. 
Biotechnology Information BLAST program. Putative core activity sites and $\mathrm{N}$-glycosylation sites were predicted by use of PROSCAN. The signal peptide of each endoPG gene was predicted with use of SignalP 3.0 (Bendtsen et al. 2004). The amino-acid sequences were aligned by use of the multiple alignment option in Clustal X. Phylogenetic trees were generated by neighbor-joining, as implemented in PAUP* 4.0 Beta (Sinauer Associates, Sunderland, MA, U.S.A.) with the default parameters. Nodal support of the tree was estimated by bootstrapping, with 1,000 pseudoreplicate data sets.

\section{Real-time qRT-PCR analysis.}

Inoculation of detached tomato leaves with zoospore suspension of Phytophthora parasitica was performed as described (Yan and Liou 2006). Total RNA was isolated from the leaves with TriZol reagent (Invitrogen, Carlsbad, CA, U.S.A.), followed by treatment with RNase-free DNase I $(0.5 \mathrm{U} / \mu \mathrm{l}$; Roche, Mannheim, Germany) at $37^{\circ} \mathrm{C}$ for $1 \mathrm{~h}$ to remove genomic DNA. Reverse transcription involved use of PowerScript reverse transcriptase (Clontech, Palo Alto, CA, U.S.A.), with $5^{\prime}-\mathrm{T}_{25} \mathrm{VN}-3^{\prime}$ (V: A, C, or G; N: A, C, G, or T) as the primer. After $10 \times$ dilution with double-distilled $\mathrm{H}_{2} \mathrm{O}, 1 \mu \mathrm{l}$ of the reverse transcription mixture was submitted for online quantitative PCR with the LightCycler system by use of the FastStart DNA master SYBR green I kit (Roche). PCR was performed in a volume of $20 \mu \mathrm{l}$ containing $2 \mu \mathrm{l}$ LightCycler FastStart DNA master SYBR green I, $3 \mathrm{mM} \mathrm{MgCl}$, and $1 \mu \mathrm{M}$ primers. The instrument settings were initial enzyme activation at $95^{\circ} \mathrm{C}$ for $10 \mathrm{~min}$, followed by 40 cycles of $95^{\circ} \mathrm{C}$ for $10 \mathrm{~s}$, $60^{\circ} \mathrm{C}$ for $5 \mathrm{~s}$, and $72^{\circ} \mathrm{C}$ for $10 \mathrm{~s}$. Design of oligonucleotide primers for quantitative PCR involved use of the GenScript Real-Time Primer Design tool (Table S2). Crude data obtained from Lightcycler were normalized, with Ubc and WS21 used as internal controls, followed by a randomization test implemented in the relative expression software tool (REST) for significance (Yan and Liou 2006). All experiments involved use of RNAs prepared from at least two biological repeats.

\section{Expression of recombinant protein \\ in Pichia pastoris and in-gel PG activity assay.}

A DNA fragment corresponding to the coding sequence of each gene that did not include the signal peptide was subcloned into pPIC- $\alpha \mathrm{C}$ (Invitrogen) with the Myc epitope and polyhistidine tag fused in-frame to its $\mathrm{C}$ terminus. The expression of recombinant proteins with an EasySelect Pichia expression kit (Invitrogen) and subsequent in-gel PG activity assays were as described (Yan and Liou 2005), with polygalacturonic acid used as the substrate. Western blot analysis followed standard procedures with anti-6X-His-tag used as the primary antibody.

\section{Construction of plasmids for PVX agroinfection.}

The binary vector pgR106 (Lu et al. 2003) and the bacterial strain C58C1 were provided by D. C. Baulcombe (The Sainsbury Laboratory, John Innes Centre, U.K.). For construction of the test clones, the signal peptide of tobacco PR1a was inserted into the ClaI and NotI sites of pgR106 and the resultant plasmid was named pgR106:SP. Subsequently, a DNA fragment corresponding to the coding sequence of each endoPG gene that did not include the signal peptide was subcloned inframe with the tobacco signal peptide into pgR106:SP by use of the NotI site. The binary expression constructs (named pgR106:pppg) were introduced into Agrobacterium tumefaciens C58C1 by electroporation, and transformants were selected on Luria-Bertanl (LB) agar supplemented with 12.5 ppm tetracycline and $25 \mathrm{ppm}$ kanamycin at $28^{\circ} \mathrm{C}$. Plasmids obtained from the transformants were then tested by PCR for the presence of
endoPG insert and further checked by DNA sequencing. Mutagenesis at the active site of the pppg genes was as described (Higuchi et al. 1988), and the mutated sequences were confirmed by DNA sequencing.

\section{PVX agroinfection assay.}

Nicotiana benthamiana plants were grown on a peat moss mixture for 24 days in the greenhouse at $25^{\circ} \mathrm{C}$ with a photoperiod of $16 \mathrm{~h}$. Three days before infiltration, Agrobacterium tumefaciens cells carrying pgR106:pppg were inoculated into LB broth supplemented with tetracycline and kanamycin at $28^{\circ} \mathrm{C}$ for $48 \mathrm{~h}$. The resultant cultures were diluted $50 \times$ with the induction medium $(90 \mathrm{mM}$ sodium phosphate buffer, $\mathrm{pH} 7.0,7$ $\mathrm{mM}$ ammonium sulfate, $1.5 \mathrm{mM}$ sodium citrate, $1 \mathrm{mM}$ $\mathrm{MgSO}_{4}, 0.2 \%$ glucose, $0.1 \mathrm{mM} \mathrm{CaCl}, 10 \mathrm{mM}$ morpholineethanesulfonic acid [MES], $20 \mu \mathrm{M}$ acetosyringone, $25 \mathrm{ppm}$ kanamycin, and $12.5 \mathrm{ppm}$ tetracycline) and were grown for another $24 \mathrm{~h}$ at $28^{\circ} \mathrm{C}$. Cells were harvested by centrifugation $\left(8,000 \mathrm{rpm}\right.$ for $15 \mathrm{~min}$ at $\left.4^{\circ} \mathrm{C}\right)$ and were resuspended with MMA (10 mM MES, pH 5.6, $10 \mathrm{mM} \mathrm{MgCl}_{2}, 200 \mu \mathrm{M}$ acetosyringone) to an optical density at $600 \mathrm{~nm}$ of 0.5 . Infiltration involved use of a needleless 1-ml syringe placed against the lower side of the leaf. Experiments were performed at least three times for each construct, with each experiment involving at least three plants per construct.

\section{Microscopy observation.}

Leaves of Nicotiana benthamiana were cut into squares of approximately $1 \mathrm{~cm}^{2}$ and were fixed in FAA solution (37\% formaldehyde/glacial acetic acid/70\% ethanol, 5:5:90) for $20 \mathrm{~h}$ at room temperature. The leaf samples were then dehydrated through graded ethanol series, were stained with safranin $\mathrm{O}$, and were embedded in Steedman's wax, made with polyethylene glycol 400 (Sigma-Aldrich, St. Louis) and 1-hexadecanol (Sigma-Aldrich) at a ratio of 9:1. Sections of $8 \mu \mathrm{m}$ were cut with a microtome and were stained with ruthenium red $(0.05 \%$, wt/vol) (Atkinson et al. 2002) and observed under a light microscope.

\section{ACKNOWLEDGMENTS}

We thank P. J. Ann for providing the Phytophthora parasitica isolate, D. C. Baulcombe for pgR106 and the bacterial strain, and the United States Department of Energy Joint Genome Institute for providing access to sequence database. This research was supported by a grant from the Nation Science Council, Taiwan (NSC95-2313-B-002-083-MY3).

\section{LITERATURE CITED}

Armand, S., Wagemaker, M. J., Sánchez-Torres, P., Kester, H. C., van Santen, Y., Dijkstra, B. W., Visser, J., and Benen, J. A. 2000. The active site topology of Aspergillus niger endopolygalacturonase II as studied by site-directed mutagenesis. J. Biol. Chem. 275:691-696.

Atkinson, R. G., Schroder, R., Hallett, I. C., Cohen, D., and MacRae, E. A. 2002. Overexpression of polygalacturonase in transgenic apple trees leads to a range of novel phenotypes involving changes in cell adhesion. Plant Physiol. 129:122-133.

Baron-Epel, O., Gharyal, P. K., and Schindler, M. 1988. Pectins as mediators of wall porosity in soybean cells. Planta 175:389-395.

Bendtsen, J. D., Nielsen, H., von Heijne, G., and Brunak, S. 2004. Improved prediction of signal peptides: SignalP 3.0. J. Mol. Biol. 340:783-795.

Boudart, G., Charpentier, M., Lafitte, C., Martinez, Y., Jauneau, A., Gaulin, E., Esquerré-Tugayé, M. T., and Dumas, B. 2003. Elicitor activity of a fungal endopolygalacturonase in tobacco requires a functional catalytic site and cell wall localization. Plant Physiol. 131:93-101.

Cole, A. L. J. 1970. Pectic enzyme activity from Phytophthora infestans. Phytochemistry 29:447-449.

Esquerré-Tugayé, M. T., Boudart, G., and Dumas, B. 2000. Cell wall degrading enzymes, inhibitory proteins, and oligosaccharides participate in the molecular dialogue between plants and pathogens. Plant Physiol. Biochem. 38:157-163. 
Gao, S., Choi, G. H., Shain, L., Nuss, D. L. 1996. Cloning and targeted disruption of enpg-1, encoding the major in vitro extracellular endopolygalacturonase of the chestnut blight fungus, Cryphonectria parasitica. Appl. Environ. Microbiol. 62:1984-1990.

Garcia-Maceira, F. I., Di Pietro, A., Huertas-Gonzalez, M. D., RuizRoldan, M. C., Roncero, M. I. 2001. Molecular characterization of an endopolygalacturonase from Fusarium oxysporum expressed during early stages of infection. Appl. Environ. Microbiol. 67:2191-2196.

Götesson, A., Marshall, J. S., Jones, D. A., and Hardham, A. R. 2002. Characterization and evolutionary analysis of a large polygalacturonase gene family in the oomycete plant pathogen Phytophthora cinnamomi. Mol. Plant-Microbe Interact. 15:907-921.

Henrissat, B. 1991. A classification of glycosyl hydrolases based on amino acid sequence similarities. Biochem. J. 280:309-316.

Higuchi, R., Krummel, B., and Saiki, R. K. 1988. A general method of in vitro preparation and specific mutagenesis of DNA fragments: Study of protein and DNA interactions. Nucleic Acids Res. 16:7351-7367.

Isshiki, A., Akimitsu, K., Yamamoto, M., and Yamamoto, H. 2001. Endopolygalacturonase is essential for citrus black rot caused by Alternaria citri but not brown spot caused by Alternaria alternata. Mol. PlantMicrobe Interact. 14:749-757.

Jiang, R. H. Y., Tyler, B. M., and Govers, F. 2006. Comparative analysis of Phytophthora genes encoding secreted proteins reveals conserved synteny and lineage-specific gene duplications and deletions. Mol. Plant-Microbe Interact. 19:1311-1321.

Kars, I., Krooshof, G. H., Wagemakers, L., Joosten, R., Benen, J. A., and van Kan, J. A. 2005. Necrotizing activity of five Botrytis cinerea endopolygalacturonases produced in Pichia pastoris. Plant J. 43:213-225.

Kasza, Z., Vagvolgyi, C., Fevre, M., and Cotton, P. 2004. Molecular characterization and in planta detection of Sclerotinia sclerotiorum endopolygalacturonase genes. Curr. Microbiol. 48:208-213.

Li, R., Rimmer, R., Buchwaldt, L., Sharpe, A. G., Seguin-Swartz, G., and Hegedus, D. D. 2004. Interaction of Sclerotinia sclerotiorum with Brassica napus: Cloning and characterization of endo- and exo-polygalacturonases expressed during saprophytic and parasitic modes. Fungal Genet. Biol. 41:754-765.

Lu, R., Malcuit, I., Moffett, P., Ruiz, M. T., Peart, J., Wu, A. J., Rathjen, J. P., Bendahmane, A., Day, L., and Baulcombe, D. C. 2003. High throughput virus-induced gene silencing implicates heat shock protein 90 in plant disease resistance. EMBO (Eur. Mol. Biol. Organ.) J. 22:5690-5699.

Miyairi, K., Fujita, K., Okuno, T, Sawai, K. 1977. A toxic protein causative of silver-leaf disease symptom on apple trees. Agri. Biol. Chem. 41:1897-1902.

Oeser, B., Heidrich, P. M., Muller, U., Tudzynski, P., and Tenberge, K. B. 2002. Polygalacturonase is a pathogenicity factor in the Claviceps purpurea/rye interaction. Fungal Genet. Biol. 36:176-186.

Poinssot, B., Vandelle, E., Bentejac, M., Adrian, M., Levis, C., Brygoo, Y. Garin, J., Sicilia, F., Coutos-Thevenot, P., and Pugin, A. 2003. The endopolygalacturonase 1 from Botrytis cinerea activates grapevine defense reactions unrelated to its enzymatic activity. Mol. Plant-Microbe
Interact. 16:553-564

Ridley, B. L., O’Neill, M. A., and Mohnen, D. 2001. Pectins: Structure, biosynthesis, and oligogalacturonide-related signaling. Phytochemistry. 57:929-967.

Scott-Craig, J. S., Cheng, Y. Q., Cervone, F., De Lorenzo, G., Pitkin, J. W., and Walton J. D. 1998. Targeted mutants of Cochliobolus carbonum lacking the two major extracellular polygalacturonases. Appl. Environ. Microbiol. 64:1497-1503.

Spiers, A. G., Edwards, W. R. N., and Hopcroft, D. H. 1987. Effects of silverleaf infection on ultrastructure of foliage of Prunus, Rosa, and Populus. New Zealand J. Bot. 25:411-423.

ten Have, A., Breuil, W. O., Wubben, J. P., Visser, J., and van Kan, J. A. 2001. Botrytis cinerea endopolygalacturonase genes are differentially expressed in various plant tissues. Fungal Genet. Biol. 33:97-105.

ten Have, A., Mulder, W., Visser, J., and van Kan, J. A. 1998. The endopolygalacturonase gene Bcpg1 is required for full virulence of Botrytis cinerea. Mol. Plant-Microbe Interact. 11:1009-1016.

Torto, T. A., Rauser, L., and Kamoun, S. 2002. The pipg1 gene of the oomycete Phytophthora infestans encodes a fungal-like endopolygalacturonase. Curr. Genet. 40:385-90.

Vorwerk, S., Somerville, S., and Somerville, C. 2004. The role of plant cell wall polysaccharide composition in disease resistance. Trends Plant Sci. 9:203-209.

Walton, J. D. 1994. Deconstructing the cell wall. Plant Physiol. 104:11131118 .

Williams, H. L., Tang, Y., and Hintz, W. E. 2002. Endopolygalacturonase is encoded by a multigene family in the basidiomycete Chondrostereum purpureum. Fungal Genet. Biol. 36:71-83.

Wubben, J. P., Mulder, W., ten Have, A., van Kan, J. A., and Visser, J. 1999. Cloning and partial characterization of endopolygalacturonase genes from Botrytis cinerea. Appl. Environ. Microbiol. 65:1596-1602.

Wubben, J. P., ten Have, A., van Kan, J. A., and Visser, J. 2000. Regulation of endopolygalacturonase gene expression in Botrytis cinerea by galacturonic acid, ambient $\mathrm{pH}$ and carbon catabolite repression. Curr. Genet. 37:152-157.

Yan, H. Z., and Liou, R. F. 2005. Cloning and analysis of pppg1, an inducible endopolygalacturonase gene from the oomycete plant pathogen Phytophthora parasitica. Fungal Genet. Biol. 42:339-350.

Yan, H. Z., and Liou, R. F. 2006. Selection of internal control genes for real-time quantitative RT-PCR assays in the oomycete plant pathogen Phytophthora parasitica. Fungal Genet. Biol. 43:430-438.

\section{AUTHOR-RECOMMENDED INTERNET RESOURCES}

United States Department of Energy JGI database: genome.jgi-psf.org/Phyra1_1

Pôle BioInformatique de Lyon Network Protein Sequence Analysis PROSCAN: npsa-pbil.ibcp.fr

GenScript Real-Time Primer Design website: www.genscript.com/ssl-bin/app/primer 